\title{
Comparative Study on Effect of Different Drying Methods on Drying Kinetics of Moringa Leaves
}

\author{
Nikita Mishra $^{1}$, S. K. Jain ${ }^{2}$ and Yogendra Kumar Jyoti ${ }^{3}$ \\ ${ }^{1}$ College of Technology and Engineering, Maharana Pratap University of \\ Agriculture and Technology Udaipur, Rajasthan, India \\ ${ }^{2}$ College of Engineering and Technology, Orissa University of \\ Agriculture and Technology, India \\ *Corresponding author
}

\section{A B S T R A C T}

\section{Keywords}

Moringa leaves,

Fluidized bed

drying, Tray drying,

Dehydration ratio,

Moisture ratio,

Drying rate

Article Info

Accepted:

24 July 2020

Available Online:

10 August 2020
Drumstick (Moringa oleifera) is an under exploited perennial vegetable species of moringaceae family, native to the Sub-Himalayan tracts of India, Pakistan, Bangladesh and Afghanistan. Fluidized bed drying and tray drying of moringa leaves were conducted at $40,50 \& 60^{\circ} \mathrm{C}$ air temperature to evaluate the drying kinetics. The average value of moisture content for fresh moringa leaves was observed to be $218.47 \%(\mathrm{db})$ for controlled sample, $269 \%(\mathrm{db})$ for water blanched sample and $290.63 \%$ (db) for chemical blanched sample. The moisture content of moringa leaves decreased with drying time under all drying condition. Moisture removal at $60^{\circ} \mathrm{C}$ was higher and faster than the other investigated temperature. It can be easily observed that the dehydration ratio decreased with increase in drying air temperatures for water blanched and chemical blanched samples, however, dehydration ratio was less for blanched samples when compared with control samples.

\section{Introduction}

Drumstick (Moringa oleifera) is an under exploited perennial vegetable species of moringaceae family, native to the SubHimalayan tracts of India, Pakistan, Bangladesh and Afghanistan (Makkar and Becker, 1997). Moringa is an effective remedy for malnutrition and has variety of essential phyto-chemicals in its leaves, pods and seeds. In fact, moringa is said to provide 7 times more vitamin $\mathrm{C}$ than oranges, 10 times more vitamin A than carrots, 17 times more calcium than milk, 9 times more protein than yoghurt, 15 times more potassium than bananas and 25 times more iron than spinach 
(Rockwood et al., 2013). Moringa leaves have been reported to be a rich source of $\beta$ carotene, protein, vitamin $\mathrm{C}$, calcium and potassium and act as a good source of natural antioxidants thus enhance the shelf-life of fat containing foods due to the presence of various types of antioxidant compounds such as ascorbic acid, flavonoids, phenolics and carotenoids (Dillard and German, 2000).

Drying is the reduction of moisture from the products and is the most important process for, preserving agricultural products. The drying process involves the transfer of mass and heat to remove water from products by evaporation. Drying causes change in the food properties including discolouring, aroma loss, textural changes, nutritive value, and changes in physical appearance and shape. Higher drying temperature reduces the drying time but may result in poor product quality, heat damage to the surface and higher energy consumption.

On the other hand, mild drying conditions with lower temperature may improve the product quality but decrease in the drying rate thus drying period is extended (Kumar et al., 2014).

Fluidized bed dryer is generally used for heat sensitive material. Fluidized bed drier has an air flow chamber, control panel, blower and heater. The air is blown from the bottom of the chamber by the blower and it is heated by the heater. The material to be dried is fed through the opening at the top of the chamber. The temperature can be controlled by the control panel. Tray dryer is an enclosed insulated chamber in which trays are placed on top of each other in trolleys. Tray dryers are used where heating and drying are essential parts of manufacturing process in industries such as chemicals, dye, stuff, pharmaceuticals, food products, colors etc.

\section{Materials and Methods}

\section{Selection of raw material}

Moringa leaves were collected from Maharana Pratap University of Agriculture and Technology Campus, Udaipur, Rajasthan. The leaves were collected in morning and then cleaning and grading was carried out. Leaves were packed in air tight plastic bags and then transported to the experimental laboratory.

\section{Drying methods}

Tray Drying

\section{Fluidized bed Drying}

The drying was carried out in tray dryer having capacity of drying $2 \mathrm{~kg}$ leaves. About $100 \mathrm{~g}$ leaves were spread on the tray in single layer. The temperature of the drying was carried out at $40^{\circ} \mathrm{C}, 50^{\circ} \mathrm{C}$ and $60^{\circ} \mathrm{C}$ at a fixed air velocity of $2 \mathrm{~m} / \mathrm{s}$. The weight of moringa leaves samples were recorded at regular time interval using top-pan electronics balance until moisture content reached constant value and average of three replications were used for calculation.

The fluidized bed dryer was simple, compact, portable and easy to operate. The cabinet contained the air distribution system and electrical controls with the provision to vary air velocity and drying air temperature. The moisture loss data during fluidized bed drying were analyzed and moisture ratios at various time intervals were calculated.

\section{Moisture content}

The reduction in moisture content of moringa leaves was recorded at an interval of $5 \mathrm{~min}$ for first 25 minute, then interval of $10 \mathrm{~min}$ for next $50 \mathrm{~min}, 15 \mathrm{~min}$ interval for next 1 hour and after that, every $30 \mathrm{~min}$ for next hour till the end of drying process. 


\section{Drying rate}

The moisture loss data at regular interval of drying experiments were determined. The removal of moisture with drying time for each drying temperature was determined and the drying rate for each time interval for each drying temperature was calculated by considering the moisture removal per unit time.

\section{Moisture ratio}

The moisture ratio of moringa leaves was calculated using following equation:

Moisture ratio $=\frac{M-M e}{M o-M e}$

Where,

$\mathrm{MR}=$ Moisture ratio

$\mathrm{M}_{\mathrm{O}}=$ Initial moisture content, per cent $(\mathrm{db})$

$\mathrm{M}_{\mathrm{e}}=$ Equilibrium moisture content, per cent (db)

$\mathrm{M}=$ Moisture content at any time $\theta$, per cent (db)

\section{Dehydration ratio}

The dehydration ratio of moringa leaves was calculated by measuring initial and final mass of moringa leaves as:

Dehydration ratio $=$

Weight of dehydrated sample

Initial weight of fresh leaves

\section{Results and Discussion}

The average initial moisture content was 218.47 per cent (db) for samples dried in hot air oven. The drying was continued till the constant weight achieved by the samples. The moisture contents were reduced to $5.89,5.73$ and 5.54 per cent $(\mathrm{db})$ for control, samples dried by $40^{\circ} \mathrm{C}, 50^{\circ} \mathrm{C}$ and $60^{\circ} \mathrm{C}$ drying air temperature. Similarly for fluidized bed drying the moisture contents were reduced to 5.29, 4.71 and 4.59 per cent (db) for control sample dried by $40^{\circ} \mathrm{C}, 50^{\circ} \mathrm{C}$ and $60^{\circ} \mathrm{C}$ drying air temperature. The moisture removal was more and faster when drying air temperature was $60^{\circ} \mathrm{C}$ than the other investigated temperatures $\left(40^{\circ} \mathrm{C}\right.$ and $\left.50^{\circ} \mathrm{C}\right)$ and lowest for $40^{\circ} \mathrm{C}$ drying air temperature as shown in the fig. 1 and fig 4.

\section{Effect of drying temperatures drying rate for different drying methods}

The variation in drying rates of moringa leaves dried with different drying air temperatures are shown in Fig. 2 and fig 5. The maximum drying rates was found at starting of drying for all three temperatures (40, 50 and $60^{\circ} \mathrm{C}$ drying air temperatures) for control samples as 2.058, 2.328 and 2.748 gwater/g-DM-h respectively for tray drying. From figures, it can be seen that maximum drying rate (6.474 g-water/g-DM-h ) was observed in control sample at $60^{\circ} \mathrm{C}$ drying air temperature followed by $5.442 \mathrm{~g}$-water/gDM-h at $50^{\circ} \mathrm{C}$ and lowest (4.394 g-water/gDM-h) at $60^{\circ} \mathrm{C}$ drying air temperature for fluidized bed drying. Further, it can be observed from Figs that the drying rate was higher showing faster moisture loss at the initial inception of the drying. The reduction in the drying rate at the end of drying may be due to the non availability of moisture as drying advances.

\section{Effect of drying temperatures on moisture ratio for different drying methods}

It can be seen from the Fig. 3. For tray drying the moisture ratio of moringa leaves decreased exponentially with drying time and varied from 1.0 to $0.00005,1.0$ to 0.00003 and 1.0 to 0.00005 for tray drying of moringa leaves at different drying air temperature. 
Similarly, for fluidized bed drying the moisture ratio varied from 1.0 to $0.00002,1.0$ to 0.001 and 1.0 to 0.0061 for different drying air temperature. From the figure 5 it was evident that moisture ratio of moringa leaves decreased with drying time in all the drying air temperatures.

Table.1 Estimation of vitamin B-6 (ppm) in Areca nut collected from different locations of Karnataka

\begin{tabular}{|l|c|c|c|c|c|c|}
\hline Property & \multicolumn{3}{|c|}{ Tray drying } & \multicolumn{3}{c|}{ Fluidized bed drying } \\
\hline Temperature & $\mathbf{4 0}^{\circ} \mathrm{C}$ & $\mathbf{5 0}^{\circ} \mathrm{C}$ & $\mathbf{6 0}^{\circ} \mathrm{C}$ & $\mathbf{4 0}^{\circ} \mathrm{C}$ & $\mathbf{5 0}^{\circ} \mathrm{C}$ & $\mathbf{6 0}^{\circ} \mathrm{C}$ \\
\hline Drying time & 330 & 300 & 270 & 210 & 190 & 150 \\
\hline Dehydration Ratio & 0.333 & 0.332 & 0.331 & 0.330 & 0.328 & 0.320 \\
\hline
\end{tabular}

Fig.1 Variation in moisture content with time for tray drying of moringa leaves

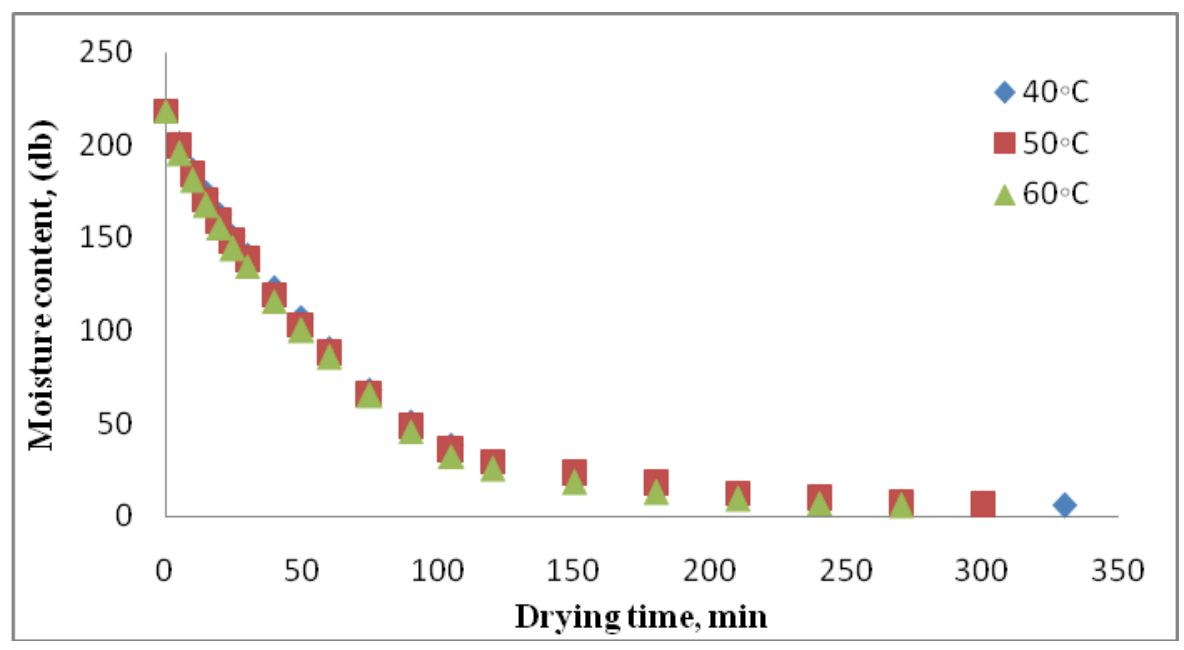

Fig.2 Variation in drying rate with moisture content for tray drying of moringa leaves

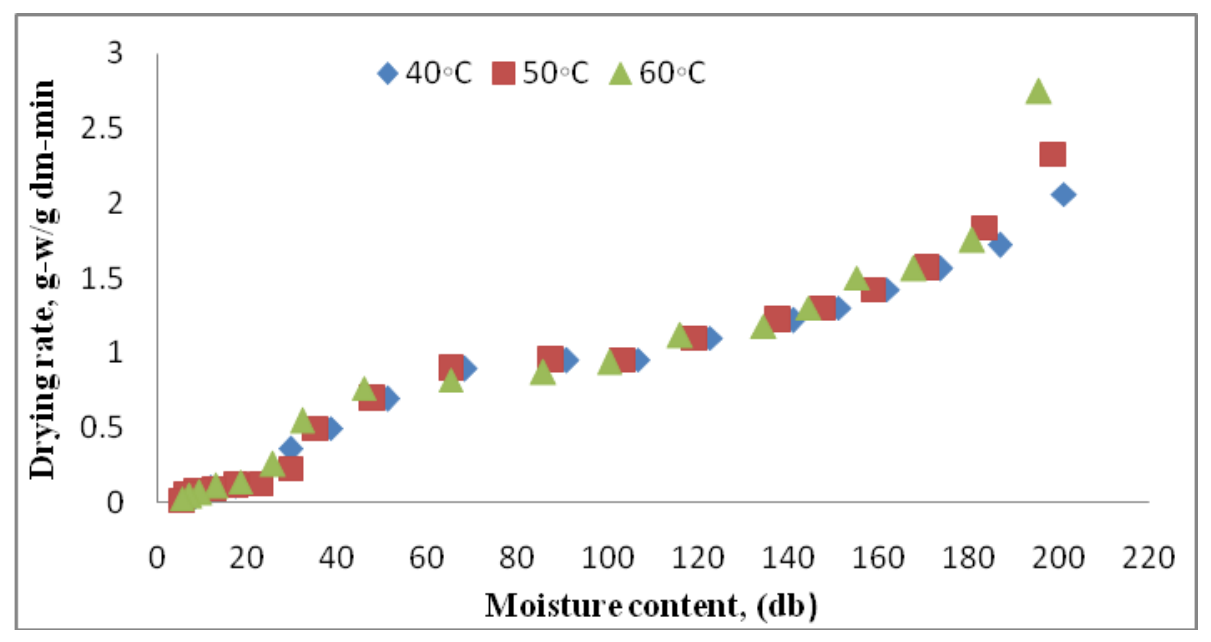


Fig.3 Variation in moisture ratio with time for tray drying of moringa leaves

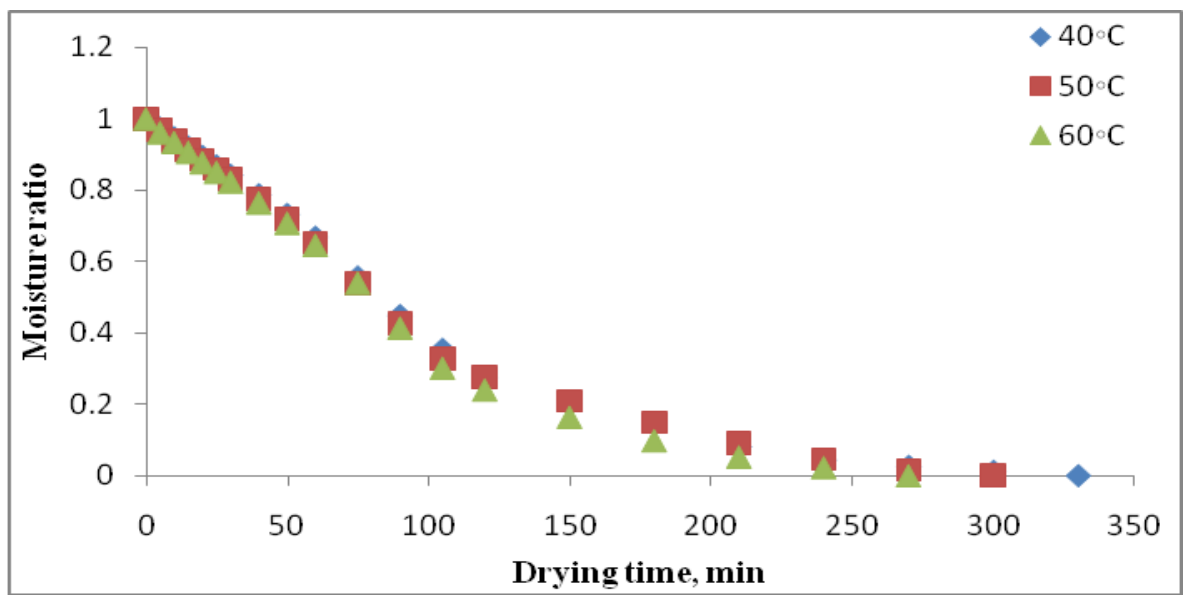

Fig.4 Variation in moisture content with time for fluidized bed drying

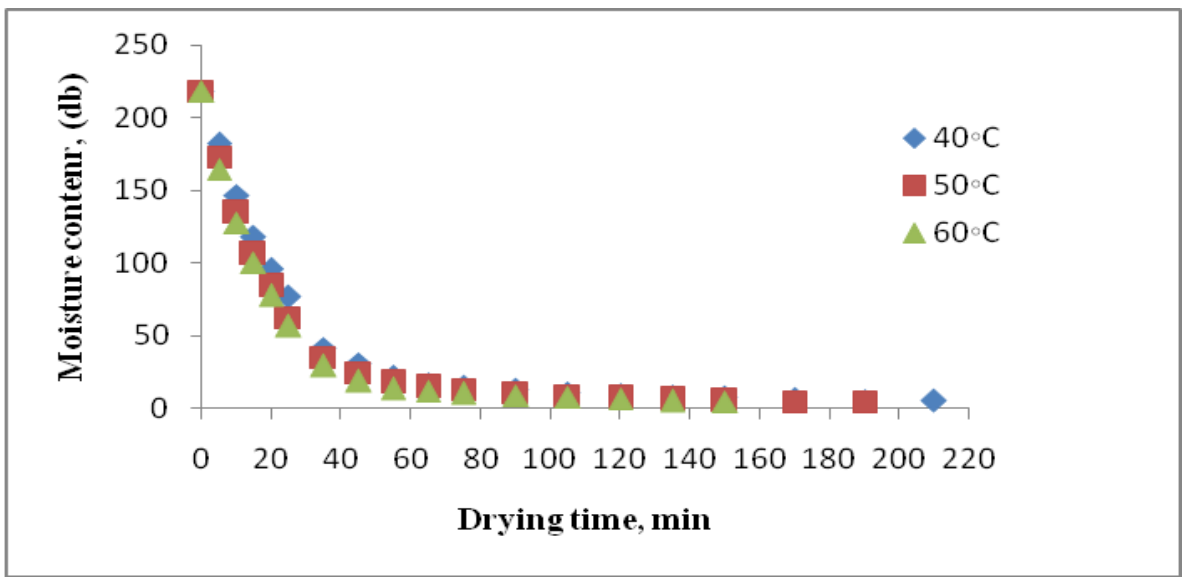

Fig.5 Variation in drying rate with moisture content for fluidized bed drying

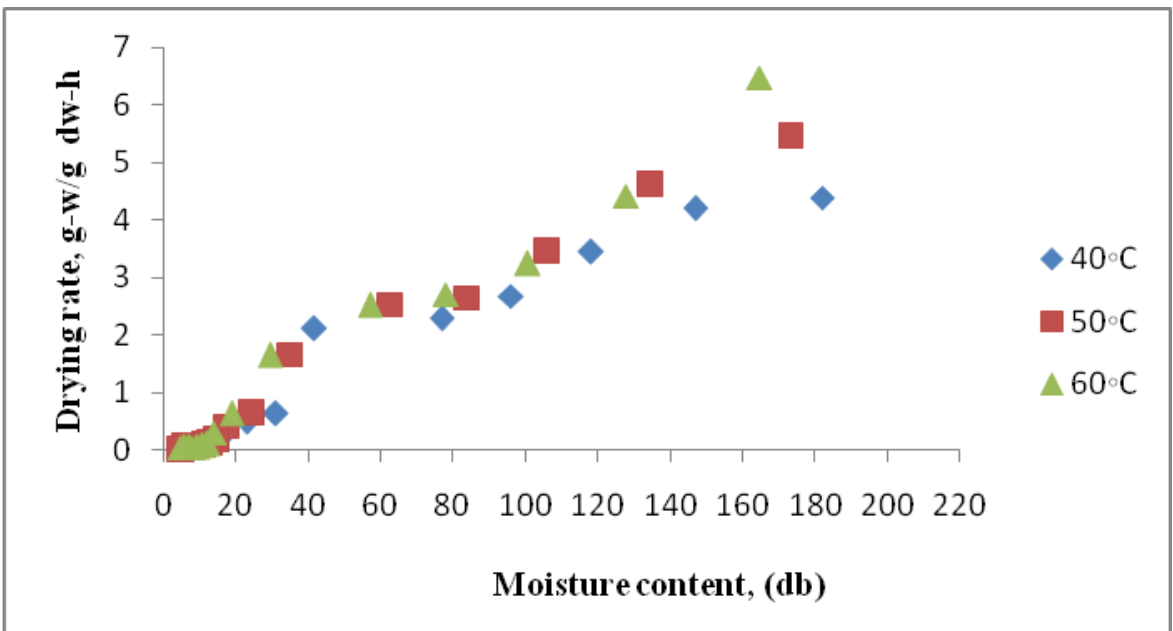


Fig.6 Variation in moisture ratio with time for fluidized bed drying

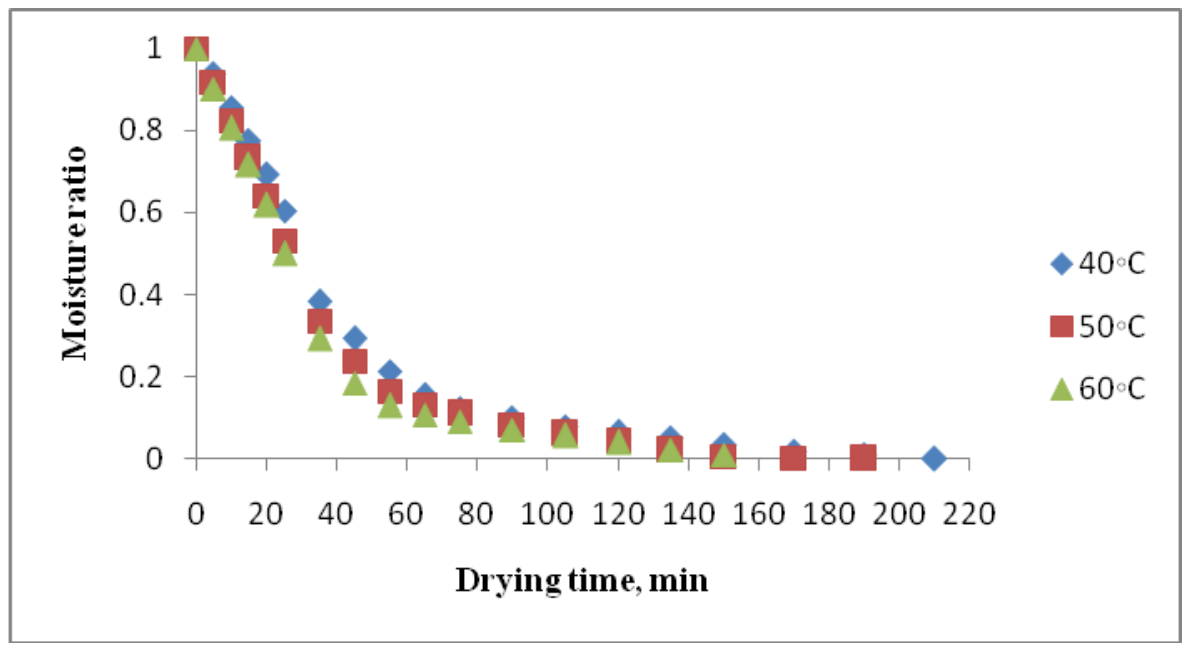

Fig.7 Effect of tray drying and fluidized bed drying on drying time for control sample

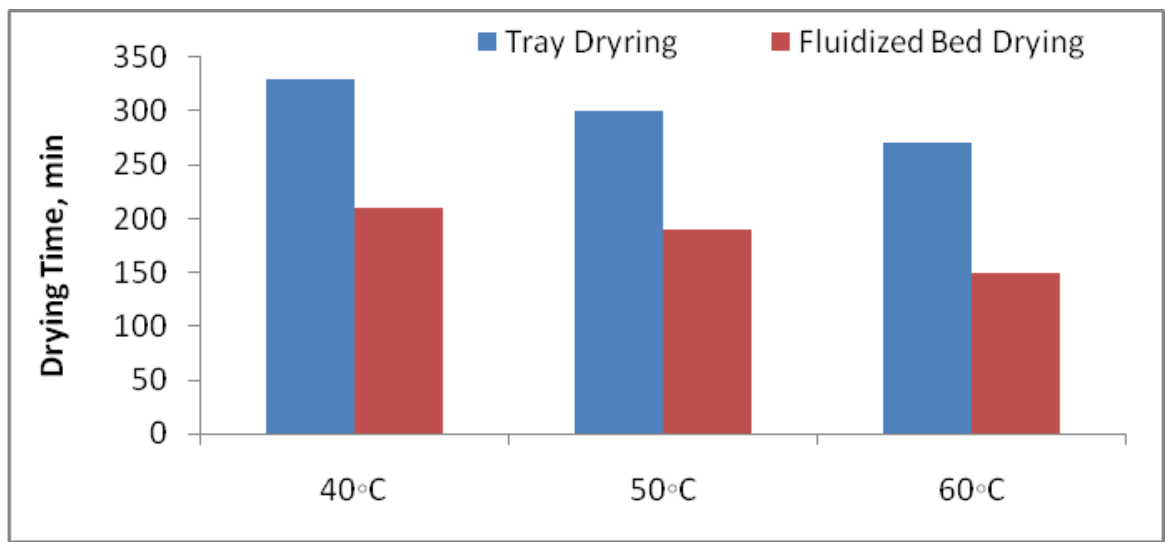

Fig.8 Effect of different drying methods on dehydration ratio for control sample

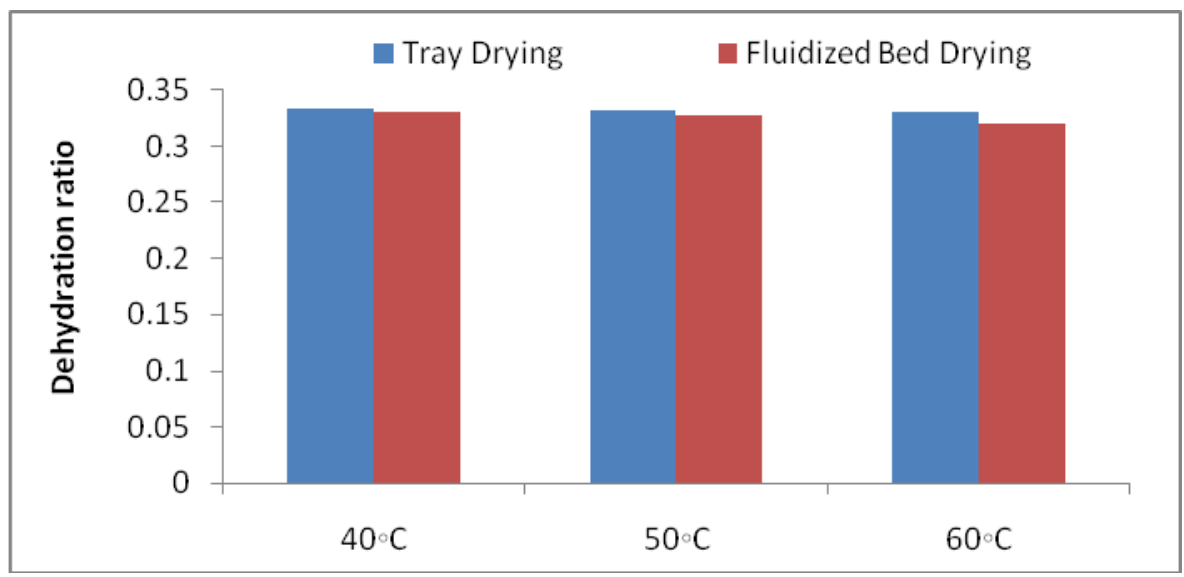




\section{Dehydration characteristics of dried moringa leaves}

It can be seen from the figure 6 that the dehydration ratio was highest for moringa leaves dried at low temperatures for all the pre-treatments and it reduced with increase in drying air temperature. The highest value $(0.3325)$ of dehydration ratio was found for control samples when drying air temperature was $40^{\circ} \mathrm{C}$ and lowest value $(0.3314)$ was obtained for $60^{\circ} \mathrm{C}$ temperature. From the data, it can be revealed that fluidized bed drying of dried product, the dehydration ratio decreased with increase in drying air temperature. The highest value $(0.33)$ of dehydration ratio was found for control samples when drying air temperature was $40^{\circ} \mathrm{C}$ and lowest value $(0.32)$ was obtained for $60^{\circ} \mathrm{C}$ temperature for fluidized bed drying.

From Table 1 and fig 7 and fig 8, the data depicts that in comparison to tray drying, fluidized bed drying took 55 per cent less time at $40^{\circ} \mathrm{C}, 61.11$ per cent less time at $50^{\circ} \mathrm{C}$ and 62.5 per cent less time at $60^{\circ} \mathrm{C}$ drying air temperature. There is 10.526 per cent decrease in value of dehydration ratio in fluidized bed drying in comparison to tray drying at $40^{\circ} \mathrm{C}$, similarly 10.563 per cent at $50^{\circ} \mathrm{C}$ and 10.60 per cent at $60^{\circ} \mathrm{C}$ showing significant variation in dehydration ratio in both drying methods

In conclusion, the constant rate drying period was absent and complete drying took place in falling rate period for both the drying methods such as for tray drying and fluidized bed drying of moringa leaves for all the pretreatments and temperatures studied, inferring that that the initial moisture content was less than the critical moisture content. The drying time required for the similar moisture reduction in fluidized bed drying was less than that for tray drying for all the pretreatments and temperatures. The dehydration ratio was highest for moringa leaves dried at low temperatures for all pre-treatments and it reduced with increase in drying air temperature. The highest value $(0.3325)$ of dehydration ratio was found for control samples when drying air temperature was $40^{\circ} \mathrm{C}$ and lowest value $(0.3314)$ was obtained for $60^{\circ} \mathrm{C}$ temperature.

\section{References}

Ali, M.A., Yusof, Y.A., Chin, N.L., Ibrahim, M.N., and Basra, S.M.A. 2014. Drying Kinetics and Colour Analysis of Moringa oleifera Leaves. Journal of Agriculture and Food Chemistry, 47(1): 4777-4781.

Balwan, S., Vijay, K.S. and Sunder, S. 2019. Comparative study of different drying methods for drying of blanched fenugreek leaves. International Journal of Current Microbiology Applied Sciences, 28(1): 1070-1076.

Cora, J.D., and German, J.B. 2000. Phytochemicals, nutraceuticals and human health. Journal of the Science of food and agriculture, 80(2): 1744-1756.

Dachana, K.B., Jyotsna , R., Indrani, D and Jamuna, P. 2010. Effect of dried moringa leaves on rheological, microstructural, nutritional, and organoleptic characteristics of cookie. World Journal of Food Science and Technology, 4(3): 92-96.

Gernah, D.I. and Sengev, I.A. (2011). Effect of processing on some chemical properties of the leaves of drumstick tree (Moringa oleifera). Niger. Food Journal, 29(1): 70-77.

Kaur, P., Kumar, A., Arora, S., and Singh, G.B. 2006. Quality of dried coriander leaves as affected by pre treatments and method of drying. Eur Food Res Technol, 223(3): 189- 194.

Palada, M.C. and Chang, L.C. 2003. Suggested cultural practices for 
moringa. International Cooperators' guide, 3(4): 545-547.

Rockwood, J.L., Anderson, B.G., and Casamatta, D.A. 2013. Potential uses of Moringa oleifera and an examination of antibiotic efficacy conferred by $\mathrm{m}$. Oleifera seed and leaf extracts using crude extraction techniques available to underserved indigenous populations. www.earthjournal.org.in, 3(2): 61-70.
Sheetal, G., Gowri, B.S., Lakshmi, A.J. and Jamuna, P. 2011. Retention of nutrients in green leafy vegetables on dehydration. J Food Sci Technol; DOI10.1007/s13197- 011-0407-z.

Vijayan, S., Arjunan T. V., and Anil K., 2017. Thin Layer Drying Characteristics of Curry Leaves. Article in thermal science, 21(2): 35 .

\section{How to cite this article:}

Nikita Mishra, S. K. Jain and Yogendra Kumar Jyoti. 2020. Comparative Study on Effect of Different Drying Methods on Drying Kinetics of Moringa Leaves. Int.J.Curr.Microbiol.App.Sci. 9(08): 3186-3193. doi: https://doi.org/10.20546/ijcmas.2020.908.363 